\title{
Hepatitis C virus genotype 3: clinical features, current and emerging viral inhibitors, future challenges
}

\author{
Vahe Shahnazariana, Daryl Ramai ${ }^{\mathrm{a}, \mathrm{b}}$, Madhavi Reddya ${ }^{\mathrm{a}}$, Smruti Mohantyc \\ The Brooklyn Hospital Center, Academic Affiliate of The Icahn School of Medicine at Mount Sinai, Clinical Affiliate \\ of The Mount Sinai Hospital, Brooklyn, NY; St George's University, Grenada, W.I.; New York Presbyterian Brooklyn \\ Methodist Hospital, Clinical Affiliate of Weill Cornell Medicine, Brooklyn, NY, USA
}

\section{Abstract}

\section{Introduction}

Viral hepatitis C (HCV) affects approximately 71 million individuals worldwide [1]. A single-stranded RNA virus of the Flaviviridae family, HCV is a major cause of chronic liver disease worldwide [2-6]. As a growing public health threat, $\mathrm{HCV}$ is one of the leading causes of disability, morbidity and mortality globally [7]. Each year, an estimated 700,000 persons die from $\mathrm{HCV}$-related complications, including

${ }^{a}$ Division of Gastroenterology, Hepatology, and Advanced Endoscopy, The Brooklyn Hospital Center, Academic Affiliate of The Icahn School of Medicine at Mount Sinai, Clinical Affiliate of The Mount Sinai Hospital, Brooklyn, NY (Vahe Shahnazarian, Daryl Ramai, Madhavi Reddy); 'bchool of Medicine, St George's University, True Blue, Grenada, W.I. (Daryl Ramai); 'Division of Gastroenterology and Hepatology, New York Presbyterian Brooklyn Methodist Hospital, Clinical Affiliate of Weill Cornell Medicine, Brooklyn, NY (Smruti Mohanty), USA

Conflict of Interest: None

Correspondence to: Vahe Shahnazarian, MD, MPH, Gastroenterology and Hepatology Fellow, Division of Gastroenterology, Hepatology, and Advanced Endoscopy, The Brooklyn Hospital Center, Academic Affiliate of The Icahn School of Medicine at Mount Sinai, Clinical Affiliate of The Mount Sinai Hospital, Brooklyn, NY 11201, USA, e-mail: vaheshahnazarian@gmail.com

Received 12 February 2018; accepted 18 April 2018; published online 4 June 2018

DOI: https://doi.org/10.20524/aog.2018.0281 cirrhosis, hepatocellular carcinoma (HCC) and liver failure [8]. Unfortunately, many people with HCV only learn about their infection when they develop symptoms from cirrhosis or liver cancer. It is estimated that $21 \%$ of acutely infected patients go undiagnosed, while $75-85 \%$ become chronically infected [9]. As a result, there have been renewed international efforts aimed at reducing the global burden of viral hepatitis, including the World Health Organization's (WHO) global health sector strategy on viral hepatitis 2016-2021 [10].

Based on genomic sequence analysis, there are seven major genotypes ( $\mathrm{HCV}$ 1-7) including 67 confirmed and 20 provisional subtypes [11]. Genotype is not only important in predicting the response to therapy but also predicts the risk of disease progression [12]. Genotype 3 is considered the most poorly understood genotype and has the lowest rate of sustained virologic response (SVR) in the pegylated-interferon era [13]. Regarded as one of the most difficult subtypes to treat, genotype 3 has a higher rate of disease progression and mortality relative to other genotypes $[13,14]$. According to a meta-analysis, accelerated progression of liver fibrosis associated with genotype 3 had an odds ratio of 1.52 in single biopsy studies compared with other genotypes, suggesting accelerated fibrosis [15]. Moreover, genotype 3 infection has been associated with a higher incidence of HCC [16]. Thus, in the last 20 years, more effective treatments have emerged to combat the virulence of genotype 3 . 


\section{Methodology}

Studies published between January 2000 and January 2018 were searched in electronic databases according to article titles, abstract contents, and relevance in the field of viral hepatitis $\mathrm{C}$ genotype 3. The databases used in this review included PubMed, MEDLINE, Embase, Google Scholar, Scopus, ClinicalTrials. gov and Cochrane Databases. The main search terms used were hepatitis $\mathrm{C}$ genotype 3, epidemiology, infection rates, steatosis, fibrosis, HIV coinfection, HCC, insulin resistance (IR), lipid metabolism, treatment, and clinical trials. We also manually searched references to identify additional relevant studies. Articles published in languages other than English were excluded.

\section{Clinical features}

\section{Epidemiology}

Genotype 3 represents $20 \%$ of all $\mathrm{HCV}$ infections worldwide [17]. It is the second most common genotype in the world, affecting approximately 54.3 million individuals, with approximately $75 \%$ of cases occurring in East Asia [18]. Genotype 3 is responsible for $54-80 \%$ of all $\mathrm{HCV}$ infections in India, and 79\% of all HCV infections in Pakistan, with higher rates reported among drug users $[17,19]$. It is also prevalent in Europe where it accounts for $30 \%$ of all HCV infections in Greece, Poland, Denmark, Finland and the UK [19]. In the US, genotype 3 is the second most common genotype and accounts for $8-13 \%$ of all HCV infections [20]. In Africa, genotype 3 is far less prevalent and makes up approximately $9 \%$ of all $\mathrm{HCV}$ infections [21].

\section{Steatosis}

Steatosis occurs as a result of the excessive accumulation of triglycerides within hepatocytes. A study reviewing liver histopathology found that genotype 3 had the highest prevalence of steatosis when compared to other subtypes [22]. This is likely due to the cytopathic effect of the genotype, which selectively interferes with the late cholesterol pathway and upregulates the expression of fatty acid synthase; however, steatosis tends to improve with SVR $[23,24]$. Steatosis has also been noted to progress more rapidly into liver fibrosis in patients infected with genotype 3 rather than other genotypes [25]. However, Chan et al reported that while genotype 3 is associated with higher rates of steatosis, current data do not show any enhanced direct viral-mediated hepatic fibrogenesis [21]. Most studies that reported a potential association with genotype 3 and severity of hepatic fibrosis were limited by small cohorts, variability in patient characteristics, such as insulin resistance (IR), body body mass index or genotype distribution, and discrepancies in methodology, particularly with respect to the grading of steatosis $[26,27]$.
A large meta-analysis of 3068 chronic hepatitis C patients from North America, Europe and Australia showed that genotype 3 was associated with steatosis, not fibrosis; multivariate analysis identified steatosis and the level of inflammatory activity on histopathology as independent predictors of disease [28]. While a direct viral association seems lacking or unclear, some studies have identified a link between higher grades of steatosis and higher rates of fibrosis [27].

While the precise pathogenic mechanisms of genotype 3-mediated steatosis are still unclear, genotype 3 appears to modulate host lipid metabolism and transportation within hepatocytes via three mechanisms: microsomal triglyceride transfer protein; sterol regulatory elementbinding protein $1 c$; and peroxisome proliferator-associated receptor- $\alpha$ [29]. Through these pathways, it is thought that intrahepatic fat sequestration or steatosis impairs the response to treatment in patients with fatty liver [25]. In a large national study of 7248 eligible subjects, the use of statins $(n=3334)$ was significantly associated with better SVR rates after antiviral therapy and lower progression of liver fibrosis and incidence of HCC [30].

\section{HCV/human immunodeficiency virus (HIV) coinfection}

Coinfection with HIV and HCV-3 is relatively common. According to a meta-analysis of over 780 studies, the global prevalence of $\mathrm{HCV} / \mathrm{HIV}$ coinfection was estimated to be about $6 \%$ [31]. In the US and Western Europe, the prevalence of coinfection is approximately $10-30 \%$ [32,33]. Coinfection with HCV-3 increases the risk of chronicity while producing a higher viral load and an inability to mount a CD4/CD8 mediated T-cell immune response [34]. Coinfection has also been associated with an accelerated progression of liver fibrosis and a reduced SVR to interferon-based regimens [35-37]. However, antiretroviral therapy has been shown to ease the progression of $\mathrm{HCV}$-associated liver injury and fibrosis by reducing HIV-related inflammation and immune dysfunction, and limiting infectivity [38-41]. Additionally, HCV treatment in coinfected patients has been associated with a reduction in the frequency of death, HIV progression, liver-related events, and reduced hazards of diabetes mellitus and possibly chronic renal failure $[42,43]$. Since HIV accelerates the natural history of HCV and liver-related complications, it is recommended that all coinfected patients be treated for chronic HCV, except those whose life expectancy is less than a few years and will not be remediated by treatment [44].

\section{Hyperlipidemia, diabetes mellitus or IR}

Lipid metabolism is intimately involved in the molecular mechanisms of the HCV infectious cycle. HCV replication influences and depends upon cholesterol uptake and efflux through different lipoprotein receptors during its entry into the host's cells [45]. Very low-density lipoprotein-associated proteins, including apolipoprotein (apo)B, apoE and 
microsomal triglyceride transfer proteins, have been shown to play a crucial role in the formation of infectious HCV particles, especially pertaining to genotype 3 [46]. HCV can bind lowdensity lipoprotein (LDL) receptors and lead to intracellular lipid deposition [47]. Patients infected with genotype 3 tend to have hypocholesterolemia and hypobetalipoproteinemia, which may account for the direct effect of the virus on lipid metabolism [48]. It appears that HCV-3 also selectively interferes with the late cholesterol pathway, a phenomenon that appears to disappear with SVR [23]. Interestingly, high LDL levels tends to predict SVR in patients treated with interferon and ribavirin (RBV) [49]. Since LDL receptors are involved in HCV entry into hepatocytes, higher LDL levels may decrease the number of LDL receptors on the cell membrane, thus decreasing cellular infectivity [49].

$\mathrm{HCV}$ core protein can induce IR by disturbing the intracellular signaling pathway of insulin [50]. In genotype 3, the presence of IR may reduce the probability of achieving SVR using interferon and RBV regimens, especially in the setting of steatosis involving more than $33 \%$ of the liver [51-54]. However, eradication of HCV appears to improve insulin sensitivity without altering fat deposits, adipokine or glucagon levels, suggesting a direct link between viral activity and IR [55]. Subjects with normal insulin sensitivity were almost three times more likely to attain SVR than those with IR [56]. Unfortunately, a prospective cohort study was unable to find an association between IR and SVR rates in genotype 1, 2 or 3 patients [57]. Additionally, Patel et al looked at genotype-specific associations with IR and liver fibrosis. While the study did report an association in genotype 1 patients, no significant association was found in the genotype 3 cohort [58]. The mechanisms of HCVmediated IR, SVR, and the genotype-specific associations remain unclear. Fortunately, new direct-acting antiviral (DAA) regimens appear unaffected by IR [54].

\section{HCC}

The incidence of HCC has been on the rise in the United States and around the world [59,60]. Genotype 3 has been associated with significantly higher rates of HCC relative to other genotypes [61]. McMahon et al studied 1080 participants for 11,171 person-years and reported that individuals infected with genotype 3 were at increased risk for HCC and liver-related death [62]. Another study showed that the risk of HCC, after adjusting for demographic and clinical characteristics, was $80 \%$ higher in patients with genotype 3 when compared to genotype 1 [63]. Likewise, McCombs et al showed in a Veteran Affairs (VA) study that the risk for developing HCC was 63\% higher with genotype 3 (HR 1.63, 95\%CI 1.47-1.79; $\mathrm{P}<0.001)$ compared with genotype 1 [14]. In addition, Ioannou et al (2018) reported that in 62,354 VA patients the treatment of HCV with DAAs reduced the risk of liver cancer by $71 \%$ [64]. The finding emphasizes the need to be vigilant in the diagnosis and early treatment of HCV even with cirrhosis of the liver.

\section{Current DAAs}

The genetic landscape exhibited by HCV has created a major challenge for developing vaccines and effective pangenotypic therapies [65]. Prior to DAAs, pegylated interferon and RBV regimens were the standard of care. However, the main limitation of those regimens was their side effects, dominated by fatigue, influenza-like symptoms, hematologic abnormalities, and neuropsychiatric symptoms [66]. These side effects have been subverted with DAAs, which treat patients facing major challenges including HCV genetic diversity, viral resistance, the influence of host genetics, advanced liver disease and other comorbidities [67-69].

Major advances in elucidating and characterizing the life cycle of HCV have led to the targeting of key stages of viral replication [70,71] (Fig. 1). DAAs target non-structural (NS) viral proteins crucial to viral RNA replication, polyprotein processing, and the assembly of infectious virions [72]. Currently, DAAs approved by the FDA for the treatment of genotype 3 are (in combination): sofosbuvir, a pangenotypic nucleotide analog inhibitor of $\mathrm{HCV}$ NS5B polymerase; daclatasvir, an inhibitor of HCV NS5A metalloprotein; velpatasvir, a next-generation pangenotypic NS5A inhibitor; and glecaprevir and pibrentasvir, a NS3/4A protease inhibitor and NS5A inhibitor, respectively [73,74].

The ASTRAL-3 trials aimed to evaluate the safety and efficacy of sofosbuvir and velpatasvir in the treatment of patients infected with genotype 3 , including treatment-naïve, treatment-experienced patients, and patients with compensated liver cirrhosis [75]. After 12-week treatment, the sofosbuvirvelpatasvir group achieved an SVR of 95\% (95\%CI 92-98\%), superior to the rate of $80 \%(95 \%$ CI $75-85 \%)$ in the sofosbuvirRBV group $(\mathrm{P}<0.001)$. The most frequently reported side effects were fatigue, headache, nausea, and insomnia.

The combination of glecaprevir and pibrentasvir was tested in the SURVEYOR-2 and ENDURANCE-3 trials [76]. In SURVEYOR-2 phase II, the combination was tested with or without RBV. The study reported an SVR of $97 \%$ for treatmentnaïve genotype 3 patients without cirrhosis after 8 weeks of treatment (without RBV). Following 12 weeks of therapy (with or without RBV), treatment-naïve genotype 3 patients showed an SVR of $100 \%$. In SURVEYOR-2 phase III, treatmentexperienced patients had either 12 or 16 weeks of glecaprevir/ pibrentasvir; in those with cirrhosis treatment-naïve patients had 12 weeks and treatment-experienced patients 16 weeks of therapy [77]. In treatment-experienced, non-cirrhotic patients, cure rates of $91 \%$ and $96 \%$ were reported in the 12 - and 16week cohorts, respectively. In the cirrhotic arms, treatmentnaïve patients had an SVR of $98 \%$ after the 12 -week regimen while the treatment-experienced patients had an SVR of $96 \%$ after 16 weeks. Studies comparing the efficacy of glecaprevir/ pibrentasvir (for 8 weeks) and sofosbuvir/daclatasvir in treatment-naïve non-cirrhotics reported similar safety and SVR profiles [78]. The study suggested that an 8-week treatment of glecaprevir/pibrentasvir could prove highly efficacious. Adding to the guidelines issued by the European Association for the Study of the Liver (EASL), the American Association for the 


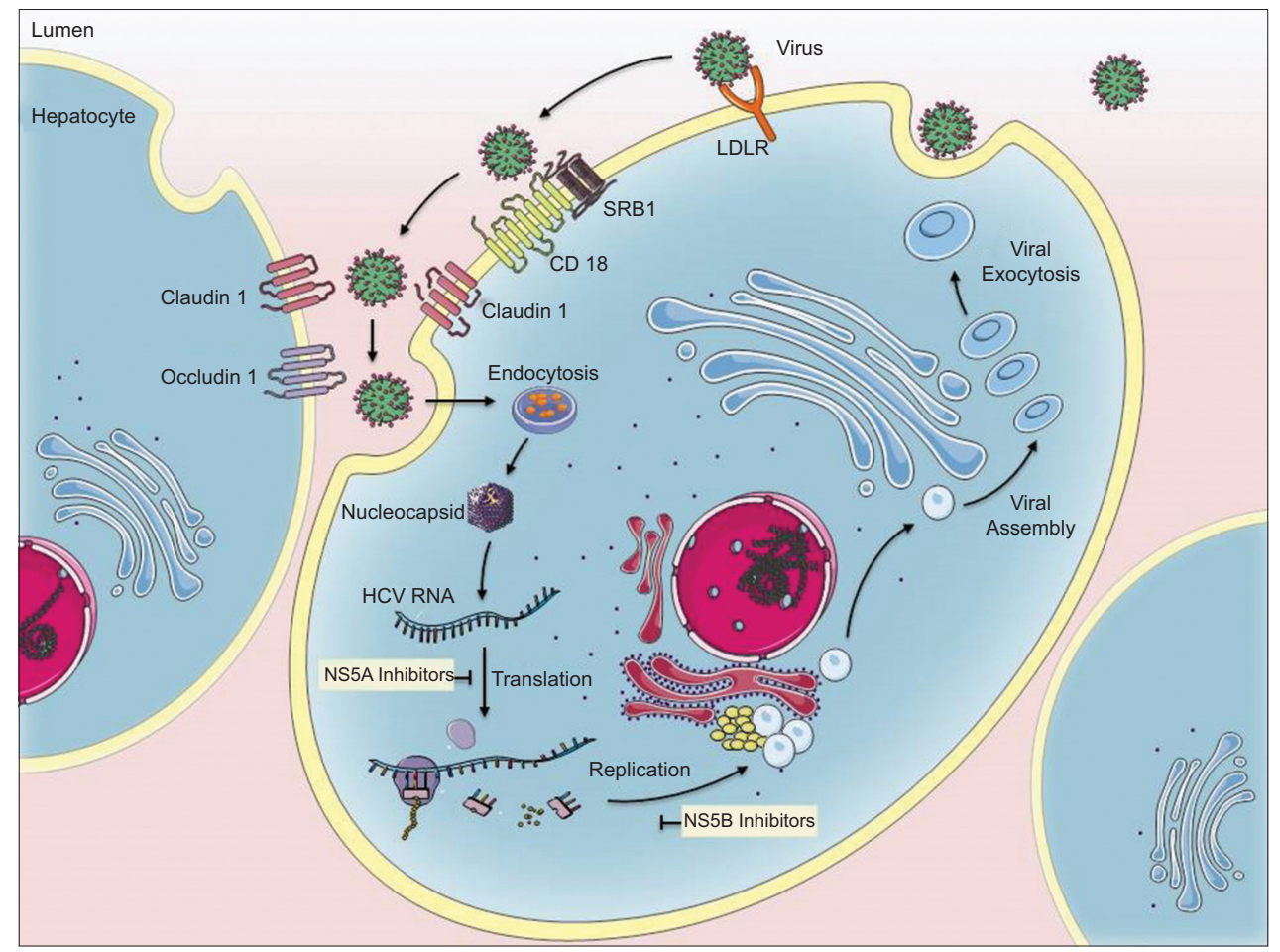

Figure 1 Illustration of stages at which NS5A and NS5B inhibitors take effect

Study of Liver Diseases and the Infectious Disease Society of America recommend the use of glecaprevir/pibrentasvir for 8 weeks in individuals without cirrhosis (Table 1) [79].

In the PROTON trial, a combination of sofosbuvir, interferon and RBV was administered for 12 weeks. It showed an SVR of $96 \%$ in treatment-naïve genotype 3 patients, some of whom had cirrhosis [80]. The BOSON trial, a phase 3 trial, evaluated the same combination, with an SVR of $93 \%$ in their treatment-naïve patients (96\% in non-cirrhotics and $91 \%$ in cirrhotics) [78]. Interferon-free cohorts receiving sofosbuvir and RBV experienced lower SVRs of $71 \%$ and $84 \%$ after being treated for 16 and 24 weeks, respectively.

In the FISSION trial, sofosbuvir and RBV for 12 weeks was compared to interferon and RBV for 24 weeks in treatmentnaïve patients [81]. However, the SVRs were only $56 \%$ and $63 \%$, respectively. In both groups, cirrhotics had a lower SVR than those without cirrhosis (34\% vs. $61 \%$ and $30 \%$ vs. $71 \%$, respectively). The POSITRON trial was for patients in whom interferon was not an option [82]. Subjects received sofosbuvir and RBV or placebo for 12 weeks and reported SVRs of $61 \%$ and $0 \%$ respectively. Cirrhotics had an SVR of $21 \%$ which noncirrhotics achieved an SVR of $68 \%$. Likewise, the VALENCE trial extended the same drug combination of sofosbuvir and RBV to 24 weeks in treatment-naïve patients. However, a much higher SVR was seen in treated patients without cirrhosis (94\%) and in cirrhotics (92\%) [83].

The ALLY-3 study included treatment-naïve patients who received a combination of sofosbuvir and daclatasvir over 12 weeks. The combination achieved an SVR of $90 \%$ and was well tolerated; the SVR was $58 \%$ in cirrhotics and $97 \%$ in noncirrhotics $[84,85]$. ALLY-3 also tested treatment-experienced patients with the same regimen and reported an SVR of $86 \%$ overall (69\% in cirrhotics and $94 \%$ in non-cirrhotics) (Table 2 ).

Velpatasvir (GS-5816) is a potent NS5A inhibitor with activity against genotypes 1-6 [86]. In the ELECTRON-2 trial, it was evaluated at different doses in combination with different drugs: sofosbuvir with $25 \mathrm{mg}$ of velpatasvir, sofosbuvir with $25 \mathrm{mg}$ of velpatasvir and RBV, sofosbuvir with $100 \mathrm{mg}$ of velpatasvir, and sofosbuvir with $10 \mathrm{mg}$ of velpatasvir and RBV, all in treatment-naïve patients [87]. The study reported SVRs of $100 \%, 88 \%, 96 \%$ and $100 \%$, respectively. It was also tested in treatment-experienced patients in the same four arms, where SVRs were $85 \%, 95 \%$, $100 \%$ and $100 \%$ in non-cirrhotic patients, and 58\%, 85\%, $88 \%$ and $96 \%$ in cirrhotic patients, respectively. The most common adverse effects were fatigue, headache and nausea, all related to RBV.

A recent meta-analysis by Berden et al showed that regimens containing sofosbuvir and velpatasvir achieved the highest treatment efficacy with RBV (SVR 99\%; 95\%CI 98100\%) and without RBV (SVR 97\%; 95\%CI 95-99\%) [88]. Analysis showed that RBV significantly increased SVR rates in patients with or without liver cirrhosis. The same regimen has also demonstrated high treatment efficacy (SVR 94\%) in patients coinfected with HIV-1 and HCV [89]. As a result, according to the EASL recommendations for the treatment of $\mathrm{HCV}$, genotype 3 mono-infected or HIV-coinfected patients should be treated with sofosbuvir and daclatasvir or with sofosbuvir and velpatasvir (for 12 weeks in treatment-naïve individuals) [90]. Treatment-experienced individuals are recommended either combinations for an extended duration of 24 weeks or the addition of RBV for 12 weeks. 
Table 1 American Association for the Study of Liver Diseases: genotype 3 treatment recommendations

\begin{tabular}{|c|c|c|c|c|c|}
\hline Population & Cirrhosis status & Recommendation & Combination & Duration & SVR \\
\hline \multirow[t]{4}{*}{ Treatment-naïve } & \multirow[t]{2}{*}{ Without cirrhosis } & $1^{\text {st }}$ line & $\begin{array}{l}\mathrm{G} / \mathrm{P} \\
\mathrm{SOF} / \mathrm{VEL}\end{array}$ & $\begin{array}{l}12 \mathrm{wk} \\
8 \mathrm{wk}\end{array}$ & $\begin{array}{l}95 \% \\
98 \%\end{array}$ \\
\hline & & $2^{\text {nd }}$ line & $\begin{array}{l}\text { DCV PO daily + SOF w/ or w/o } \\
\text { RBV }\end{array}$ & $12 \mathrm{wk}$ & $90 \%$ \\
\hline & \multirow[t]{2}{*}{$\begin{array}{l}\text { With compensated } \\
\text { cirrhosis }\end{array}$} & $1^{\text {st }}$ line & $\begin{array}{l}\text { SOF/VEL } \\
\text { G/P }\end{array}$ & $\begin{array}{l}12 \mathrm{wk} \\
12 \mathrm{wk}\end{array}$ & $\begin{array}{c}93 \% \\
100 \%\end{array}$ \\
\hline & & $2^{\text {nd }}$ line & $\begin{array}{l}\mathrm{DCV}+\mathrm{SOF} \text { w/ or w/o weight } \\
\text { based RBV } \\
\text { SOF/VEL/voxilaprevir* }\end{array}$ & $\begin{array}{l}24 \mathrm{wk} \\
12 \mathrm{wk}\end{array}$ & $\begin{array}{l}86 \% \\
96 \%\end{array}$ \\
\hline \multirow[t]{4}{*}{ Treatment-experienced } & \multirow[t]{2}{*}{ Without cirrhosis } & $1^{\text {st }}$ line & SOF/VEL & $12 \mathrm{wk}$ & $97 \%$ \\
\hline & & $2^{\text {nd }}$ line & $\begin{array}{l}\mathrm{DCV}+\mathrm{SOF} \\
\mathrm{G} / \mathrm{P} \\
\text { SOF/VEL/voxilaprevir }\end{array}$ & $\begin{array}{l}12 \mathrm{wk} \\
16 \mathrm{wk} \\
12 \mathrm{wk}\end{array}$ & $\begin{array}{l}94 \% \\
96 \% \\
84 \%\end{array}$ \\
\hline & \multirow[t]{2}{*}{$\begin{array}{l}\text { With Compensated } \\
\text { Cirrhosis }\end{array}$} & $1^{\text {st }}$ line & $\begin{array}{l}\text { SOF/VEL/voxilaprevir } \\
\text { Elbasvir/grazoprevir + SOF }\end{array}$ & $\begin{array}{l}12 \mathrm{wk} \\
12 \mathrm{wk}\end{array}$ & $\begin{array}{c}96 \% \\
100 \%\end{array}$ \\
\hline & & $2^{\text {nd }}$ line & $\begin{array}{l}\text { SOF/VEL w/ weight based RBV } \\
\text { G/P }\end{array}$ & $\begin{array}{l}12 \mathrm{wk} \\
16 \mathrm{wk}\end{array}$ & $\begin{array}{l}89 \% \\
96 \%\end{array}$ \\
\hline Treatment-Naïve & $\begin{array}{l}\text { With decompensated } \\
\text { cirrhosis and RBV eligible }\end{array}$ & $1^{\text {st }}$ line & $\begin{array}{l}\mathrm{DCV}+\mathrm{SOF} \text { w/ low initial dose of } \\
\mathrm{RBV} \text { (increase as tolerated) } \\
\text { SOF/VEL w/ weight based RBV }\end{array}$ & $\begin{array}{l}12 \mathrm{wk} \\
12 \mathrm{wk}\end{array}$ & $\begin{array}{c}83-94 \% \\
85 \%\end{array}$ \\
\hline Treatment-Naive & $\begin{array}{l}\text { With decompensated } \\
\text { cirrhosis and RBV } \\
\text { ineligible }\end{array}$ & $1^{\text {st }}$ line & $\begin{array}{l}\mathrm{DCV}+\mathrm{SOF} \\
\text { SOF/VEL }\end{array}$ & $\begin{array}{l}24 \mathrm{wk} \\
24 \mathrm{wk}\end{array}$ & $\begin{array}{l}60 \% \\
50 \%\end{array}$ \\
\hline Treatment-experienced & $\begin{array}{l}\text { With decompensated } \\
\text { cirrhosis and Sofosbuvir- } \\
\text { or NS5A-based treatment } \\
\text { failure }\end{array}$ & $1^{\text {st }}$ line & SOF/ VEL & $24 \mathrm{wk}$ & $78 \%$ \\
\hline
\end{tabular}

${ }^{*}$ When RAS Y93H is present

SVR, sustained virologic response; SOF, sofosbuvir; IFN, interferon; RBV, ribavirin; DCV, daclatasvir; G, glecaprevir; P, pibrentasvir; VEL, velpatasvir

Today, many of these treatments are very expensive compared to prior regimens of interferon and RBV. The sofosbuvir, ledipasvir and RBV regimen costs approximately $\$ 73,000$ per quality-adjusted life year (QALY), whereas the sofosbuvir and daclatasvir combination costs more than $\$ 396,000$ per QALY [19]. However, from a societal perspective, treatment with novel HCV therapies appears to be costeffective compared to RBV and pegylated interferon-based treatments $[91,92]$. The use of DAAs has led to dramatically higher SVR rates along with fewer side effects. The current recommendations for the treatment of chronic HCVgenotype 3 are summarized in Table 1.

\section{Emerging next-generation antivirals}

Future developments consist of next-generation DAAs capable of overcoming resistance barriers and offer a broader spectrum of activity against all genotypes, including glecaprevir, pibrentasvir, voxilaprevir, uprifosbuvir, grazoprevir, ruzasvir, AL-335, simeprevir, and odalasvir [93]. The C-SWIFT trial combined grazoprevir, elbasvir and sofosbuvir in the treatment of naïve patients with and without cirrhosis [94]. Non-cirrhotic patients received the therapy for 8 or 12 weeks and achieved SVRs of $93 \%$ and $100 \%$, respectively. Cirrhotic patients achieved an SVR of $91 \%$ after a 12 -week course. Similarly, the C-ISLE study assessed the efficacy and safety of elbasvir and grazoprevir plus sofosbuvir with and without RBV, though in patients with compensated cirrhosis [95]. Among treatment-naïve participants, SVR at 8-weeks was 91\% (21/23) in those treated with RBV. Following treatment for 12-weeks without RBV, SVR was 96\% (23/24). Among treatment-experienced participants, with and without RBV, SVR was $94 \%(17 / 18)$ and $100 \%(17 / 17)$ in the 12 week arm, respectively, and $94 \%(17 / 18)$ in the 16-week arm. Five individuals reported significant adverse effects, including pneumonia, chest pain, opiate overdose, cellulitis, and decreased creatinine. Paritaprevir (ABT-450), an NS3/4 inhibitor, is administered with ritonavir (ABT-450/r) [96]. As a pharmaco-enhancer, ritonavir has no activity against HCV; instead, it inhibits the metabolism of paritaprevir, thereby increasing peak and trough drug exposures and allowing for a once-daily dose of ABT-450 [97]. The NAVIGATOR trial combined ABT-450/r with ombitasvir (ABT-267), an NS5A 
inhibitor, for 12 weeks in genotype 3 treatment-naïve noncirrhotic patients, achieving SVR rates of $50 \%$ without RBV and just 9\% with RBV [98]. Though the medication was well tolerated, the low SVRs prompted discontinuation of the trial. Similarly, in patients with or without cirrhosis, the QUARTZ II-III trial combinations of ombitasvir/paritaprevir/ritonavir plus sofosbuvir with or without RBV showed an overall SVR of $98 \%$ after 12 weeks [98]. The study noted that combining DAAs with complementary mechanisms of action and virological targets may be an effective therapeutic strategy.

Other novel inhibitors are being studied, including uprifosbuvir (MK-3682; NS5B inhibitor), ruzasvir (MK8408; NS5A inhibitor), grazoprevir (NS3 inhibitor), and voxilaprevir (NS3/4A inhibitor) [99]. The C-BREEZE-2 trial looked at the efficacy of ruzasvir and uprifosbuvir in treating genotypes 1 to 6 for 12 weeks [100]. However, because of the suboptimal genotype 3 SVRs ( $80 \%$ in patients without cirrhosis vs. $68 \%$ in patients with cirrhosis), as well as virological relapse, the combination was deemed therapeutically ineffective (Table 3 ).

In phase II of C-CREST-2, a triple combination of uprifosbuvir, ruzasvir and grazoprevir was tested [101]. The overall SVR in genotype 3, treatment-naïe, non-cirrhotic patients ranged from $86-95 \%$, suggesting that the 8 -week treatment duration was suboptimal [102]. In phase III of the C-CREST 2 trial, the same triple combination, with and without RBV, was investigated at 8,12 , and 16 weeks [102]. The overall SVR for genotype 3 patients was $96 \%$. In the 8 -week arm, SVR was $94 \%$ and $98 \%$, without and with RBV, respectively. In the cirrhotic subgroup, only 1 patient relapsed out of 74 , and this patient was in the 16-week treatment (with RBV) group.

Phase II of the LEPTON trial evaluated a triple combination of sofosbuvir, velpatasvir and GS-9857, a nextgeneration NS3/4A protease inhibitor [100]. The treatment was tested in treatment-naive patients with compensated cirrhosis, interferon/RBV failures with cirrhosis, and DAA failures with and without cirrhosis. The naïve group had a duration of 6 weeks while the experienced group had a duration of 8 weeks. The naïve group had an SVR of $83 \%$ while the experienced group had an SVR of $100 \%$, which included four prior DAA non-responders. However, the study was inadequately powered and these results should therefore be interpreted cautiously.

In the POLARIS-3 trial, treatment-naïve and experienced patients with cirrhosis were treated with sofosbuvir and velpatasvir for 12 weeks, or sofosbuvir, velpatasvir, and voxilaprevir for 8 weeks [103]. The trial enrolled patients who had not previously received treatment with DAAs. Overall, both groups achieved an SVR of $96 \%$ after 12-weeks, which included one withdrawn consent and an unrelated death. Treatment-naïve patients with cirrhosis had an SVR of $96 \%$ on the triple therapy, while treatment-experienced patients with cirrhosis had an SVR of $97 \%$. About $2 \%$ of study participants experienced adverse events.

Finally, MIV-802, an NS5B inhibitor, was tested to assess its antiviral activity against genotype 3 in vitro [104]. Preclinical studies found that MIV-802 had greater antiviral activity against genotype 3 than did sofosbuvir, which supported its consideration for further development [105]. Overall, next-generation HCV DAAs appear to be clinically effective in treating a wide patient population. SVR rates for next-generation DAAs are either equal to or higher than those for first-generation DAAs. This new class of therapeutics promise to be easy to use, highly efficient, pan-genotypic, once-daily, all-oral, and interferon- and RBV-free [93].

\section{Future challenges}

HCV drug development in the last decade has overcome many challenges and has addressed gaps in care, such as pan-genotype coverage, adverse side effects, and coverage for HIV coinfected individuals and cirrhotics. Achieving clinical SVR has become less of an issue in genotype 3 infected patients, once considered difficult to treat [106]. Studies in certain patient populations, such as children, pregnant women and nursing mothers, are lacking and represent an unmet need [107]. Additionally, while most HCV medications are metabolized by the liver, DAA options for persons with severe chronic kidney disease remain limited or contraindicated [108]. Furthermore, the sample size from subgroup analysis emerging from the clinical trials of nextgeneration DAAs must be interpreted cautiously. As a result, larger sample sizes are needed to evaluate the clinical efficacy within special cohorts.

Moreover, given that cost plays a role in the distribution and uptake of treatments, it remains to be seen how cost will affect public health. Our next challenge lies in overcoming cost barriers if we are to truly eradicate HCV genotype 3 [109]. We must address drug prices to ensure universal access. We must also combine these efforts with harm reduction aimed at reintroducing new and resistant strains of $\mathrm{HCV}$. More importantly, in order to achieve the strategic goal set by the $\mathrm{WHO}$, which aims to eliminate $\mathrm{HCV}$, researchers, healthcare providers, policy makers, affected communities, advocates, pharmaceutical and diagnostics industries, and governments around the world will have to work together [110]. FaladeNwulia et al noted that reducing reinfection and achieving $\mathrm{HCV}$ elimination goals involve coupling $\mathrm{HCV}$ treatment with harm reduction and targeted behavioral interventions; reinfection rates should be viewed as an indicator of the uptake of HCV treatment [111].

Furthermore, although DAAs have been successful in treating $\mathrm{HCV}$, their financial burden does not exclude the possibility of the use and development of a vaccine that may serve a crucial preventative role [112]. While vaccines are available for preventing hepatitis $\mathrm{A}$ and $\mathrm{B}$, the goal of $\mathrm{HCV}$ vaccine development is protection from $\mathrm{HCV}$ persistence. Several candidate vaccines have progressed to clinical testing after promising results in chimpanzees [113]. Two vaccination mechanisms are currently being investigated using T-cell mediated immunity and eliciting antibodies [114]. However, the complex transcriptional profile of hepatitis $\mathrm{C}$ continues to be challenge vaccine development. 
Table 2 Current treatment options with direct acting antivirals

\begin{tabular}{|c|c|c|c|}
\hline Population & Study & Combination & SVR (\%) \\
\hline \multirow[t]{12}{*}{ Treatment-naïve } & PROTON & $\mathrm{SOF}+\mathrm{IFN}+\mathrm{RBV} 12 \mathrm{wk}$ & No cirrhosis: 96 \\
\hline & FISSION & $\mathrm{SOF}+\mathrm{RBV} 12 \mathrm{wk}$ & $\begin{array}{l}\text { No cirrhosis: } 61 \\
\text { Cirrhosis: } 34\end{array}$ \\
\hline & POSITRON & $\mathrm{SOF}+\mathrm{RBV} 12 \mathrm{wk}$ & $\begin{array}{l}\text { No cirrhosis: } 68 \\
\text { Cirrhosis: } 21\end{array}$ \\
\hline & VALENCE & $\mathrm{SOF}+\mathrm{RBV} 24 \mathrm{wk}$ & $\begin{array}{l}\text { No Cirrhosis: } 94 \\
\text { Cirrhosis: } 92\end{array}$ \\
\hline & BOSON & SOF + IFN + RBV $12 \mathrm{wk}$ & $\begin{array}{l}\text { No cirrhosis: } 96 \\
\text { Cirrhosis: } 91\end{array}$ \\
\hline & & SOF + RBV 16 wk & $\begin{array}{l}\text { No cirrhosis: } 83 \\
\text { Cirrhosis: } 57\end{array}$ \\
\hline & & $\mathrm{SOF}+\mathrm{RBV} 24 \mathrm{wk}$ & $\begin{array}{l}\text { No cirrhosis: } 90 \\
\text { Cirrhosis: } 82\end{array}$ \\
\hline & ALLY-3 & $\mathrm{SOF}+\mathrm{DCV} 12 \mathrm{wk}$ & $\begin{array}{l}\text { No cirrhosis: } 97 \\
\text { Cirrhosis: } 58\end{array}$ \\
\hline & ELECTRON-2 & $\begin{array}{l}\text { SOF + LDV } 12 w k \\
\text { SOF + LDV + RBV } 12 w k\end{array}$ & $\begin{array}{l}\text { No cirrhosis: } 64 \\
\text { No cirrhosis: } 100\end{array}$ \\
\hline & SURVEYOR-2 & $\begin{array}{l}G / P+R B V 8 w k \\
G / P+R B V 12 w k\end{array}$ & $\begin{array}{l}\text { No cirrhosis: } 97 \\
\text { Cirrhosis: } 100\end{array}$ \\
\hline & ASTRAL-3 & $\begin{array}{l}\text { SOF + VEL } 8 w k \\
\text { SOF + VEL + RBV } 8 w k \\
\text { SOF + VEL } 8 w k\end{array}$ & $\begin{array}{l}\text { No cirrhosis: } 100 \\
\text { No cirrhosis: } 88 \\
\text { No cirrhosis: } 96\end{array}$ \\
\hline & & $\begin{array}{l}\text { SOF + VEL + RBV } 8 w k \\
\text { SOF + VEL } 12 w k\end{array}$ & $\begin{array}{l}\text { No cirrhosis: } 100 \\
\text { Cirrhosis: } 91\end{array}$ \\
\hline \multirow[t]{9}{*}{ Treatment-experienced } & LONESTAR-2 & $\mathrm{SOF}+\mathrm{IFN}+\mathrm{RBV} 12 \mathrm{wk}$ & $\begin{array}{l}\text { No cirrhosis: } 83 \\
\text { Cirrhosis: } 83\end{array}$ \\
\hline & FUSION & $\mathrm{SOF}+\mathrm{RBV} 12 \mathrm{wk}$ & $\begin{array}{l}\text { No cirrhosis: } 37 \\
\text { Cirrhosis: } 19\end{array}$ \\
\hline & & SOF + RBV 16 wk & $\begin{array}{l}\text { No cirrhosis: } 63 \\
\text { Cirrhosis: } 61\end{array}$ \\
\hline & VALENCE & $\mathrm{SOF}+\mathrm{RBV} 24 \mathrm{wk}$ & $\begin{array}{l}\text { Overall: } 70 \\
\text { No cirrhosis: } 85 \\
\text { Cirrhosis: } 60\end{array}$ \\
\hline & BOSON & $\mathrm{SOF}+\mathrm{IFN}+\mathrm{RBV} 12 \mathrm{wk}$ & $\begin{array}{l}\text { No cirrhosis: } 94 \\
\text { Cirrhosis: } 86\end{array}$ \\
\hline & & SOF + RBV 16 wk & $\begin{array}{l}\text { No cirrhosis: } 76 \\
\text { Cirrhosis: } 47\end{array}$ \\
\hline & & $\mathrm{SOF}+\mathrm{RBV} 24 \mathrm{wk}$ & $\begin{array}{l}\text { No cirrhosis: } 82 \\
\text { Cirrhosis: } 77\end{array}$ \\
\hline & ELECTRON-2 & $\mathrm{SOF}+\mathrm{LDV}+\mathrm{RBV} 12 \mathrm{wk}$ & $\begin{array}{l}\text { No cirrhosis: } 89 \\
\text { Cirrhosis: } 73\end{array}$ \\
\hline & SURVEYOR-2 & $\begin{array}{l}G / P+R B V 12 w k \\
G / P+R B V 16 w k \\
G / P+R B V 12 w k\end{array}$ & $\begin{array}{l}\text { No cirrhosis: } 91 \\
\text { No cirrhosis: } 96 \\
\text { Cirrhosis: } 96\end{array}$ \\
\hline
\end{tabular}

SVR, sustained virologic response; SOF, sofosbuvir; IFN, interferon; RBV, ribavirin; DCV, daclatasvir; LDV, ledipasvir; VEL, velpatasvir; G/P, glecaprevir / pibrentasvir

HCV reinfection should be minimized but not feared as we work towards HCV elimination. Rather, reinfection should be viewed as an indication of the uptake of hepatitis $C$ treatment in populations most likely to sustain ongoing HCV epidemics. HCV reinfections should be minimized by coupling HCV treatment with harm reduction and well-designed targeted behavioral interventions.

\section{Concluding remarks}

$\mathrm{HCV}$ represents a global health threat. Specifically, genotype 3 is known to have a rapid disease progression relative to other genotypes, leading to advanced stages of liver disease far earlier. Through the manipulation of lipid 
Table 3 Next-generation treatments

\begin{tabular}{|c|c|c|c|}
\hline Population & Study & Combination & SVR (\%) \\
\hline \multirow[t]{7}{*}{ Treatment-naïve } & C-SWIFT & Elbasvir + Grazoprevir + SOF & $\begin{array}{l}\text { No cirrhosis, } 8 \text { wk: } 93 \\
\text { No cirrhosis, } 12 \text { wk: } 100 \\
\text { Cirrhosis, } 12 \text { wk: } 91\end{array}$ \\
\hline & C-ISLE & Elbasvir + Grazoprevir + SOF & $\begin{array}{l}\text { Cirrhosis, } 8 \text { wk: } 91 \\
\text { Cirrhosis, } 12 \text { wk: } 96\end{array}$ \\
\hline & NAVIGATOR & $\begin{array}{l}\text { ABT- } 450 / r+\text { Ombitasvir } \\
\text { ABT- } 450 / r+\text { Ombitasvir + RBV }\end{array}$ & $\begin{array}{l}\text { No cirrhosis, } 12 \text { wk: } 40 \\
\text { No cirrhosis, } 12 \text { wk: } 9\end{array}$ \\
\hline & QUARTZ II-III & $\begin{array}{l}\text { Ombitasvir + Paritaprevir + Ritonavir + SOF } \\
\text { Ombitasvir + Paritaprevir + Ritonavir + SOF + RBV } \\
\text { Ombitasvir + Paritaprevir + Ritonavir + SOF + RBV }\end{array}$ & $\begin{array}{l}\text { No cirrhosis, } 12 \text { wk: } 98 \\
\text { No cirrhosis, } 12 \text { wk: } 91 \\
\text { Cirrhosis, } 12 \text { wk: } 100\end{array}$ \\
\hline & C-CREST-2 & $\begin{array}{l}\text { Ruzasvir + Uprifosbuvir + Grazoprevir } \\
\text { Ruzasvir + Uprifosbuvir + Grazoprevir + RBV } \\
\text { Ruzasvir + Uprifosbuvir + Grazoprevir } \\
\text { Ruzasvir + Uprifosbuvir + Grazoprevir + RBV }\end{array}$ & $\begin{array}{l}\text { No cirrhosis, } 8 / 12 \text { wk: } 95 \\
\text { No cirrhosis, } 12 \text { wk: } 100 \\
\text { Cirrhosis, } 12 \text { wk: } 97 \\
\text { Cirrhosis, } 12 \text { wk: } 100\end{array}$ \\
\hline & LEPTON & SOF + VEL + GS-9857 & $\begin{array}{l}\text { Cirrhosis, } 6 \text { wk: } 83 \\
\text { Cirrhosis, } 8 \text { wk: } 100\end{array}$ \\
\hline & POLARIS-3 & $\begin{array}{l}\text { SOF + VEL + Voxilaprevir } \\
\text { SOF + VEL }\end{array}$ & $\begin{array}{l}\text { Cirrhosis, } 8 \text { wk: } 96 \\
\text { Cirrhosis, } 12 \text { wk: } 96\end{array}$ \\
\hline \multirow[t]{3}{*}{ Treatment-experienced } & C-ISLE & Elbasvir + Grazoprevir + SOF & $\begin{array}{l}\text { Cirrhosis, } 12 \text { wk: } 100 \\
\text { Cirrhosis, } 16 \text { wk: } 94\end{array}$ \\
\hline & LEPTON & SOF + VEL + GS-9857 & $\begin{array}{l}\text { No cirrhosis, } 8 \text { wk: } 100 \\
\text { Cirrhosis, } 8 \text { wk: } 100\end{array}$ \\
\hline & C-CREST-2 & $\begin{array}{l}\text { Ruzasvir + Uprifosbuvir + Grazoprevir } \\
\text { Ruzasvir + Uprifosbuvir + Grazoprevir + RBV }\end{array}$ & $\begin{array}{l}\text { No cirrhosis, } 12 \text { wk: } 97 \\
\text { Cirrhosis, } 12 \text { wk: } 100 \\
\text { No cirrhosis, } 12 \text { wk: } 93 \\
\text { Cirrhosis, } 12 \text { wk: } 100\end{array}$ \\
\hline
\end{tabular}

SVR, sustained virologic response; SOF, sofosbuvir; IFN, interferon; RBV, ribavirin; VEL, velpatasvir; ABT-450/r, Paritaprevir/ritonavir

metabolic pathways, steatosis impairs the treatment response. However, even in patients with advanced liver disease, new DAA regimens are slowly turning the tide against genotype 3. A high SVR can be achieved in patients with a spectrum of liver disease, as well as those coinfected with HIV. New DAA regimens are also better tolerated by patients, since they have fewer adverse side-effects. We believe that with this expanded armamentarium, genotype 3 should no longer be considered difficult to treat.

\section{References}

1. Polaris Observatory HCV Collaborators. Global prevalence and genotype distribution of hepatitis $C$ virus infection in 2015: a modelling study. Lancet Gastroenterol Hepatol 2017;2:161-176.

2. Lavanchy D. The global burden of hepatitis C. Liver Int 2009;29(Suppl 1):74-81.

3. Chen SL, Morgan TR. The natural history of hepatitis $C$ virus (HCV) infection. Int J Med Sci 2006;3:47-52.

4. Seeff LB. The history of the "natural history" of hepatitis C (19682009). Liver Int 2009;29(Suppl 1):89-99.

5. Klevens RM, Hu DJ, Jiles R, Holmberg SD. Evolving epidemiology of hepatitis $\mathrm{C}$ virus in the United States. Clin Infect Dis 2012;55(Suppl 1):S3-S9.
6. Smith BD, Morgan RL, Beckett GA, Centers for Disease Control and Prevention. Recommendations for the identification of chronic hepatitis $\mathrm{C}$ virus infection among persons born during 1945-1965. MMWR Recomm Rep 2012;61:1-32.

7. Stanaway JD, Flaxman AD, Naghavi M, et al. The global burden of viral hepatitis from 1990 to 2013: findings from the Global Burden of Disease Study 2013. Lancet 2016;388:1081-1088.

8. World Health Organization. WHO issuing updated guidelines for treatment of hepatitis C infection. http://www.who.int/hepatitis/ news-events/hepatitis-c-guidelines-2016-story/en/[Accessed May 1, 2018].

9. Centers for Disease Control and Prevention. The ABCs of hepatitis. Retrieved March 4, 2011, from http://www.cdc.gov/ hepatitis/Resources/Professionals/PDFs/ABCTable.pdf.

10. WHO. Global health sector strategy on viral hepatitis 2016-2021. Towards ending viral hepatitis. 2016. from http://apps.who.int/ iris/bitstream/10665/246177/1/WHO-HIV-2016.06-eng.pdf [Accessed May 1, 2018].

11. Smith DB, Bukh J, Kuiken C, et al. Expanded classification of hepatitis $\mathrm{C}$ virus into 7 genotypes and 67 subtypes: updated criteria and genotype assignment web resource. Hepatology 2014;59:318-327.

12. Ge D, Fellay J, Thompson AJ, et al. Genetic variation in IL28B predicts hepatitis $\mathrm{C}$ treatment-induced viral clearance. Nature 2009;461:399-401.

13. Sarin SK, Kumar CK. Treatment of patients with genotype 3 chronic hepatitis $\mathrm{C}-$ current and future therapies. Liver Int 2012;32(Suppl 1):141-145. 
14. McCombs J, Matsuda T, Tonnu-Mihara I, et al. The risk of long-term morbidity and mortality in patients with chronic hepatitis C: results from an analysis of data from a Department of Veterans Affairs Clinical Registry. JAMA Intern Med 2014;174:204-212.

15. Probst A, Dang T, Bochud M, Egger M, Negro F, Bochud PY. Role of hepatitis $C$ virus genotype 3 in liver fibrosis progression-a systematic review and meta-analysis. J Viral Hepat 2011;18:745-759.

16. Nkontchou G, Ziol M, Aout M, et al. HCV genotype 3 is associated with a higher hepatocellular carcinoma incidence in patients with ongoing viral C cirrhosis. J Viral Hepat 2011;18:e516-e522.

17. Gower E, Estes C, Blach S, Razavi-Shearer K, Razavi H. Global epidemiology and genotype distribution of the hepatitis $\mathrm{C}$ virus infection. J Hepatol 2014;61:S45-S57.

18. Messina JP, Humphreys I, Flaxman A, et al. Global distribution and prevalence of hepatitis $\mathrm{C}$ virus genotypes. Hepatology 2015;61:77-87.

19. Ampuero J, Romero-Gómez M, Reddy KR. Review article: HCV genotype 3 - the new treatment challenge. Aliment Pharmacol Ther 2014;39:686-698.

20. Kohli A, Shaffer A, Sherman A, Kottilil S. Treatment of hepatitis C: a systematic review. JAMA 2014;312:631-640.

21. Chan A, Patel K, Naggie S. Genotype 3 infection: the last stand of hepatitis C virus. Drugs 2017;77:131-144.

22. Gondeau C, Pageaux GP, Larrey D. Hepatitis C virus infection: Are there still specific problems with genotype 3? World $J$ Gastroenterol 2015;21:12101-12113.

23. Clark PJ, Thompson AJ, Vock DM, et al. Hepatitis C virus selectively perturbs the distal cholesterol synthesis pathway in a genotype-specific manner. Hepatology 2012;56:49-56.

24. Lee YA, Friedman SL. Reversal, maintenance or progression: what happens to the liver after a virologic cure of hepatitis C? Antiviral Res 2014;107:23-30.

25. Buti M, Esteban R. Hepatitis C virus genotype 3: a genotype that is not 'easy to treat'. Expert Rev Gastroenterol Hepatol 2014;9:375385.

26. Westin J, Nordlinder H, Lagging M, Norkrans G, Wejstål R. Steatosis accelerates fibrosis development over time in hepatitis C virus genotype 3 infected patients. J Hepatol 2002;37:837-842.

27. Adinolfi LE, Gambardella M, Andreana A, Tripodi MF, Utili R, Ruggiero G. Steatosis accelerates the progression of liver damage of chronic hepatitis $\mathrm{C}$ patients and correlates with specific $\mathrm{HCV}$ genotype and visceral obesity. Hepatology 2001;33:1358-1364.

28. Leandro G, Mangia A, Hui J, et al. Relationship between steatosis, inflammation, and fibrosis in chronic hepatitis C: a meta-analysis of individual patient data. Gastroenterology 2006;130:1636-1642.

29. Abenavoli L, Masarone M, Peta V, et al. Insulin resistance and liver steatosis in chronic hepatitis $\mathrm{C}$ infection genotype 3. World J Gastroenterol 2014;20:15233-15240.

30. Butt AA, Yan P, Bonilla H, et al; ERCHIVES (Electronically Retrieved Cohort of HCV Infected Veterans) Study Team. Effect of addition of statins to antiviral therapy in hepatitis C virus-infected persons: Results from ERCHIVES. Hepatology 2015;62:365-374.

31. Platt L, Easterbrook P, Gower E, et al. Prevalence and burden of HCV coinfection in people living with HIV: a global systematic review and meta-analysis. Lancet Infect Dis 2016;16:797-808.

32. Berenguer J, Rivero A, Jarrín I, et al. Human immunodeficiency virus/hepatitis C virus coinfection in Spain: prevalence and patient characteristics. Open Forum Infect Dis 2016;3:ofw059.

33. Lo Re V $3^{\text {rd }}$, Kallan MJ, Tate JP, et al. Hepatic decompensation in antiretroviral-treated patients co-infected with HIV and hepatitis $\mathrm{C}$ virus compared with hepatitis $\mathrm{C}$ virus-monoinfected patients: a cohort study. Ann Intern Med 2014;160:369-379.

34. Abdel-Hakeem MS, Shoukry NH. Protective immunity against hepatitis C: many shades of gray. Front Immunol 2014;5:274.

35. Konerman MA, Mehta SH, Sutcliffe CG, et al. Fibrosis progression in human immunodeficiency virus/hepatitis $\mathrm{C}$ virus coinfected adults: prospective analysis of 435 liver biopsy pairs. Hepatology 2014;59:767-775.

36. Chen JY, Feeney ER, Chung RT. HCV and HIV coinfection: mechanisms and management. Nat Rev Gastroenterol Hepatol 2014;11:362-371.

37. Peters L, Klein MB. Epidemiology of hepatitis C virus in HIVinfected patients. Curr Opin HIV AIDS 2015;10:297-302.

38. Pineda JA, García-García JA, Aguilar-Guisado M, et al; Grupo para el Estudio de las Hepatitis Víricas de la Sociedad Andaluza de Enfermedades Infecciosas (SAEI). Clinical progression of hepatitis C virus-related chronic liver disease in human immunodeficiency virus-infected patients undergoing highly active antiretroviral therapy. Hepatology 2007;46:622-630.

39. Bräu N, Salvatore M, Ríos-Bedoya CF, et al. Slower fibrosis progression in HIV/HCV-coinfected patients with successful HIV suppression using antiretroviral therapy. J Hepatol 2006;44:47-55.

40. Qurishi N, Kreuzberg C, Lüchters G, et al. Effect of antiretroviral therapy on liver-related mortality in patients with HIV and hepatitis C virus coinfection. Lancet 2003;362:1708-1713.

41. Lin W, Weinberg EM, Chung RT. Pathogenesis of accelerated fibrosis in HIV/HCV coinfection. J Infect Dis 2013;207(Suppl 1):S13-S18.

42. Berenguer J, Rodríguez-Castellano E, Carrero A, et al; GESIDA HIV/HCV Cohort Study Group. Eradication of hepatitis C virus and non-liver-related non-acquired immune deficiency syndrome-related events in human immunodeficiency virus/ hepatitis C virus coinfection. Hepatology 2017;66:344-356.

43. Limketkai BN, Mehta SH, Sutcliffe CG, et al. Relationship of liver disease stage and antiviral therapy with liver-related events and death in adults coinfected with HIV/HCV. JAMA 2012;308:370-378.

44. Kumar RN, Balba GP. Managing the HIV/HCV-co-infected patient in the direct-acting antiviral era: a review of pertinent drug interactions. Curr Treat Options Infect Dis 2017;9:411-424.

45. Douam F, Lavillette D, Cosset FL. The mechanism of HCV entry into host cells. Prog Mol Biol Transl Sci 2015;129:63-107.

46. Paul D, Madan V, Bartenschlager R. Hepatitis C virus RNA replication and assembly: living on the fat of the land. Cell Host Microbe 2014;16:569-579.

47. Aizawa Y, Seki N, Nagano T, Abe H. Chronic hepatitis C virus infection and lipoprotein metabolism. World J Gastroenterol 2015;21:10299-10313.

48. Felmlee DJ, Hafirassou ML, Lefevre M, Baumert TF, Schuster C. Hepatitis C virus, cholesterol and lipoproteins-impact for the viral life cycle and pathogenesis of liver disease. Viruses 2013;5:1292-1324.

49. Saigal S, Choudhary NS, Saraf N, et al. Genotype 3 and higher low-density lipoprotein levels are predictors of good response to treatment of recurrent hepatitis $\mathrm{C}$ following living donor liver transplantation. Indian J Gastroenterol 2015;34:305-309.

50. Pazienza V, Clément $S$, Pugnale $\mathrm{P}$, et al. The hepatitis $\mathrm{C}$ virus core protein of genotypes $3 \mathrm{a}$ and $\mathrm{lb}$ downregulates insulin receptor substrate 1 through genotype-specific mechanisms. Hepatology 2007;45:1164-1171.

51. Poustchi H, Negro F, Hui J, et al. Insulin resistance and response to therapy in patients infected with chronic hepatitis $\mathrm{C}$ virus genotypes 2 and 3. J Hepatol 2008;48:28-34.

52. D'Souza R, Sabin CA, Foster GR. Insulin resistance plays a significant role in liver fibrosis in chronic hepatitis $\mathrm{C}$ and in the response to antiviral therapy. Am J Gastroenterol 2005;100:1509-1515.

53. Dai CY, Huang JF, Hsieh MY, et al. Insulin resistance predicts 
response to peginterferon-alpha/ribavirin combination therapy in chronic hepatitis C patients. J Hepatol 2009;50:712-718.

54. Knobler H, Stephen M. Hepatitis $\mathrm{C}$ and insulin action: An intimate relationship. World J Hepatol 2016;8:131-138.

55. Milner KL, Jenkins AB, Trenell M, et al. Eradicating hepatitis C virus ameliorates insulin resistance without change in adipose depots. J Viral Hepat 2014;21:325-332.

56. Eslam M, Aparcero R, Kawaguchi T, et al. Meta-analysis: insulin resistance and sustained virological response in hepatitis C. Aliment Pharmacol Ther 2011;34:297-305.

57. Fattovich G, Covolo L, Bibert S, et al; ITAHEC Study Group. IL28B polymorphisms, IP-10 and viral load predict virological response to therapy in chronic hepatitis C. Aliment Pharmacol Ther 2011;33:1162-1172.

58. Patel S, Jinjuvadia R, Patel R, Liangpunsakul S. Insulin resistance is associated with significant liver fibrosis in chronic hepatitis C patients: A systemic review and meta-analysis. J Clin Gastroenterol 2016;50:80-84.

59. White DL, Thrift AP, Kanwal F, Davila J, El-Serag HB. Incidence of hepatocellular carcinoma in all 50 United States, from 2000 through 2012. Gastroenterol 2017;152:812-820.

60. Hallager S, Ladelund S, Kjaer M, et al. Hepatocellular carcinoma in patients with chronic hepatitis $\mathrm{C}$ and cirrhosis in Denmark: a nationwide cohort study. J Viral Hepat 2018;25:47-55.

61. Kattakuzhy S, Levy R, Rosenthal E, Tang L, Wilson E, Kottilil S. Hepatitis C genotype 3 disease. Hepatol Intern 2016;10:861-870.

62. McMahon BJ, Bruden D, Townshend-Bulson L, et al. Infection with hepatitis $C$ virus genotype 3 is an independent risk factor for end-stage liver disease, hepatocellular carcinoma, and liverrelated death. Clin Gastroenterol Hepatol 2017;15:431-437.

63. Kanwal F, Kramer JR, Ilyas J, Duan Z, El-Serag HB. HCV genotype 3 is associated with an increased risk of cirrhosis and hepatocellular cancer in a national sample of U.S. Veterans with HCV. Hepatology 2014;60:98-105.

64. Ioannou GN, Green PK, Berry K. HCV eradication induced by direct-acting antiviral agents reduces the risk of hepatocellular carcinoma. J Hepatol 2018;68:25-32.

65. Timm J, Roggendorf M. Sequence diversity of hepatitis C virus: implications for immune control and therapy. World $J$ Gastroenterol 2007;13:4808-4817.

66. Fried MW. Side effects of therapy of hepatitis C and their management. Hepatology 2002;36:S237-S244.

67. Scheel TK, Rice CM. Understanding the hepatitis C virus life cycle paves the way for highly effective therapies. Nat Med 2013;19:837-849.

68. Pearlman BL, Traub N. Sustained virologic response to antiviral therapy for chronic hepatitis $\mathrm{C}$ virus infection: a cure and so much more. Clin Infect Dis 2011;52:889-900.

69. Aghemo A, Colombo M. No time for bullies in hepatitis C virus therapy: genotype 3 conquered? Gastroenterology 2016;150:1241-1243.

70. Pawlotsky JM. New hepatitis C therapies: the toolbox, strategies, and challenges. Gastroenterol 2014;146:1176-1192.

71. Aghemo A, De Francesco R. New horizons in hepatitis C antiviral therapy with direct-acting antivirals. Hepatology 2013;58:428438.

72. Ashfaq UA, Javed T, Rehman S, Nawaz Z, Riazuddin S. An overview of HCV molecular biology, replication and immune responses. Virol J 2011;8:161.

73. Johnson SW, Thompson DK, Raccor B. Hepatitis C virusgenotype 3: update on current and emergent therapeutic interventions. Curr Infect Dis Rep 2017;19:22.

74. Food and Drug Administration. FDA approves Mavyret for Hepatitis C. https://www.fda.gov/NewsEvents/Newsroom/ PressAnnouncements/ucm570038.htm [Accessed May 1, 2018].

75. Foster GR, Afdhal N, Roberts SK, et al; ASTRAL-3 Investigators.
Sofosbuvir and velpatasvir for HCV genotype 2 and 3 infection. N Engl J Med 2015;373:2608-2617.

76. Asselah T, Kowdley KV, Zadeikis N, et al. Efficacy of glecaprevir/ pibrentasvir for 8 or 12 weeks in patients with Hepatitis C virus genotype 2, 4, 5, or 6 infection without cirrhosis. Clin Gastroenterol Hepatol 2018;16:417-426.

77. Wyles D, Poordad F, Wang S, et al. Glecaprevir/pibrentasvir for HCV genotype 3 patients with cirrhosis and/or prior treatment experience: a partially randomized phase III clinical trial. Hepatology 2017;2:514-523.

78. Foster GR, Pianko S, Brown A, et al. Efficacy of sofosbuvir plus ribavirin with or without peginterferon-alfa in patients with hepatitis $\mathrm{C}$ virus genotype 3 infection and treatment-experienced patients with cirrhosis and hepatitis $C$ virus genotype 2 infection. Gastroenterology 2015;149:1462-1470.

79. AASLD/IDSA recommendations for testing, managing, and treating Hepatitis C. https://www.hcvguidelines.org/[Accessed May 1, 2018].

80. Lawitz E, Lalezari JP, Hassanein T, et al. Sofosbuvir in combination with peginterferon alfa-2a and ribavirin for noncirrhotic, treatment-naive patients with genotypes 1,2 , and 3 hepatitis $\mathrm{C}$ infection: a randomised, double-blind, phase 2 trial. Lancet Infect Dis 2013;13:401-408.

81. Lawitz E, Mangia A, Wyles D, et al. Sofosbuvir for previously untreated chronic hepatitis $\mathrm{C}$ infection. $N$ Engl $J$ Med 2013;368:1878-1887.

82. Jacobson IM, Gordon SC, Kowdley KV, et al; FUSION Study. Sofosbuvir for hepatitis C genotype 2 or 3 in patients without treatment options. N Engl J Med 2013;368:1867-1877.

83. Younossi ZM, Stepanova M, Zeuzem S, et al. Patient-reported outcomes assessment in chronic hepatitis C treated with sofosbuvir and ribavirin: the VALENCE study. J Hepatol 2014;61:228-234.

84. Nelson DR, Cooper JN, Lalezari JP, et al; ALLY-3 Study Team. All-oral 12-week treatment with daclatasvir plus sofosbuvir in patients with hepatitis C virus genotype 3 infection: ALLY-3 phase III study. Hepatology 2015;61:1127-1135.

85. Leroy V, Angus P, Bronowicki JP, et al. Daclatasvir, sofosbuvir, and ribavirin for hepatitis $C$ virus genotype 3 and advanced liver disease: A randomized phase III study (ALLY-3+). Hepatology 2016;63:1430-1441.

86. Lawitz E, Sullivan G, Rodriguez-Torres M, et al. Exploratory trial of ombitasvir and ABT-450/r with or without ribavirin for HCV genotype 1, 2, and 3 infection. J Infect 2015;70:197-205.

87. Gane EJ, Hyland RH, An D, et al. Sofosbuvir/ledipasvir fixed dose combination is safe and effective in difficult-to-treat populations including genotype-3 patients, decompensated genotype-1 patients, and genotype-1 patients with prior sofosbuvir treatment experience. J Hepatol 2014;60:S3-S4.

88. Berden FA, Aaldering BR, Groenewoud H, IntHout J, Kievit W, Drenth JP. Identification of the best direct-acting antiviral regimen for patients with hepatitis $\mathrm{C}$ virus genotype 3 infection: a systematic review and network meta-analysis. Clin Gastroenterol Hepatol 2017;15:349-359.

89. Wyles D, Bräu N, Kottilil S, et al; ASTRAL-5 Investigators. Sofosbuvir and velpatasvir for the treatment of hepatitis $\mathrm{C}$ virus in patients coinfected with human immunodeficiency virus type 1: an open-label, phase 3 study. Clin Infect Dis 2017;65:6-12.

90. European Association for the Study of the Liver. Electronic address: easloffice@easloffice.eu. EASL Recommendations on Treatment of Hepatitis C 2016. J Hepatol 2017;66:153-194.

91. Chhatwal J, Kanwal F, Roberts MS, Dunn MA. Cost-effectiveness and budget impact of hepatitis C virus treatment with sofosbuvir and ledipasvir in the United States. Ann Intern Med 2015;162:397-406

92. Najafzadeh M, Andersson K, Shrank WH, et al. Cost-effectiveness 
of novel regimens for the treatment of hepatitis $\mathrm{C}$ virus. Ann Intern Med 2015;162:407-419.

93. Ruiz I, Chevaliez S, Pawlotsky JM. Next-generation direct-acting antiviral drug-based regimens for hepatitis C. Curr Hepatology Rep 2017;16:184-191.

94. Lawitz E, Poordad F, Gutierrez JA, et al. Short-duration treatment with elbasvir/grazoprevir and sofosbuvir for hepatitis C: a randomized trial. Hepatology 2017;65:439-450.

95. Foster GR, Agarwal K, Cramp ME, et al. Elbasvir/Grazoprevir and Sofosbuvir for HCV genotype 3 infection with compensated cirrhosis: a randomized trial. Hepatology 2018 Feb 23 [Epub ahead of print]. doi: 10.1002/hep.29852.

96. Kowdley KV, Lawitz E, Poordad F, et al. Phase $2 \mathrm{~b}$ trial of interferon-free therapy for hepatitis $\mathrm{C}$ virus genotype $1 . \mathrm{N} \mathrm{Engl} \mathrm{J}$ Med 2014;370:222-232.

97. Carrion AF, Gutierrez J, Martin P. New antiviral agents for the treatment of hepatitis C: ABT-450. Expert Opin Pharmacother 2014;15:711-716.

98. Shafran SD, Shaw D, Charafeddine M, et al. Efficacy and safety results of patients with HCV genotype 2 or 3 infection treated with ombitasvir/paritaprevir/ritonavir and sofosbuvir with or without ribavirin (QUARTZ II-III). J Viral Hepat 2018;25:118125.

99. Gane E, Poordad F, Wang S, et al. High efficacy of ABT-493 and ABT-530 treatment in patients with HCV genotype 1 or 3 infection and compensated cirrhosis. Gastroenterology 2016;151:651-659.e1.

100. Lawitz E, Gane EJ, Feld JJ, et al. C-BREEZE 2: efficacy and safety of a two-drug direct-acting antiviral agent (DAA) regimen ruzasvir $180 \mathrm{mg}$ and uprifosbuvir $450 \mathrm{mg}$ for 12 weeks in adults with chronic hepatitis $\mathrm{C}$ virus (HCV) genotype (GT) 1, 2, 3, 4, or 6. Hepatology 2017;66:A34-A35.

101. Lawitz E, Buti M, Vierling JM, et al. Safety and efficacy of a fixed-dose combination regimen of grazoprevir, ruzasvir, and uprifosbuvir with or without ribavirin in participants with and without cirrhosis with chronic hepatitis $\mathrm{C}$ virus genotype 1 , 2, or 3 infection (C-CREST-1 and C-CREST-2, part B): two randomised, phase 2, open-label trials. Lancet Gastroenterol Hepatol 2017;2:814-823.

102. Borgia G, Maraolo AE, Nappa S, Gentile I, Buonomo AR. NS5B polymerase inhibitors in phase II clinical trials for HCV infection. Expert Opin Investig Drugs 2018;27:243-250.
103. Foster G, Peter JR, Sergio B, et al. A randomized, phase 3 trial of sofosbuvir/velpatasvir/voxilaprevir for 8 weeks and sofosbuvir/velpatasvir for 12 weeks for patients with genotype 3 HCV infection and cirrhosis: the POLARIS-3 study. American Association for the Study of Liver Diseases Annual Meeting; 11-15 Nov 2016; Boston.

104. Lindqvist A, Kylefjord $\mathrm{H}$, Wähling $\mathrm{H}$, et al. Preclinical characterization of MIV-802, a novel uridine nucleotide HCV NS5B polymerase inhibitor, for treatment of hepatitis C virus infection. J Hepatol 2015;62:S58.

105. Lana E, Brenndorfer E, Kylefjord H, et al. MIV-802, a uridine nucleotide prodrug, is a more potent inhibitor of hepatitis C virus genotype 3 replication than sofosbuvir. J Hepatol 2017;66:S322-S323.

106. Morisco F, Granata R, Camera S, et al; ITAL-C consortium. Optimization of direct anti-viral agent treatment schedule: Focus on HCV genotype 3. United European Gastroenterol J 2018;6:225-237.

107. Naggie S, Muir AJ. Oral combination therapies for hepatitis C virus infection: successes, challenges, and unmet needs. Annu Rev Med 2017;68:345-358.

108. Falade-Nwulia O, Suarez-Cuervo C, Nelson DR, Fried MW, Segal JB, Sulkowski MS. Oral direct-acting agent therapy for hepatitis $\mathrm{C}$ virus infection: a systematic review. Ann Intern Med 2017; 166:637-648.

109. Dore GJ, Feld JJ. Hepatitis C virus therapeutic development: in pursuit of "perfectovir". Clin Infect Dis 2015;60:1829-1836.

110. Grebely J, Dore GJ, Morin S, Rockstroh JK, Klein MB. Elimination of HCV as a public health concern among people who inject drugs by 2030 - what will it take to get there? J Int AIDS Soc 2017;20:22146.

111. Falade-Nwulia O, Sulkowski MS, Merkow A, Latkin C, Mehta $\mathrm{SH}$. Understanding and addressing hepatitis $\mathrm{C}$ reinfection in the oral direct-acting antiviral era. J Viral Hepat 2018;25:220-227.

112. Stone J, Martin NK, Hickman M, et al. The potential impact of a hepatitis $\mathrm{c}$ vaccine for people who inject drugs: is a vaccine needed in the age of direct-acting antivirals? PloS One 2016;11:e0156213.

113. Liang TJ. Current progress in development of hepatitis $C$ virus vaccines. Nat Med 2013;19:869-878.

114. Walker CM. Designing an HCV vaccine: a unique convergence of prevention and therapy? Curr Opin Virol 2017;23:113-119. 